\title{
A comparative ultrastructural analysis of eyes in leeches (Hirudinea: Rhynchobdellida, Arhynchobdellida)
}

\author{
N.V. Shakurova, A.R. Gataullina \\ Kazan Federal University, Kazan, 420008, Russian Federation.E-mail: ntlshakurova@gmail.com
}

\begin{abstract}
The hirudineas seem to be unique among the Clitellata because of presence of a complete phaosomal organs - pigmented eyes - that are widespread only in leeches. The last works on the ultrastructure of leech eyes were done in the 60's. The ultrastructure of eyes of the rhynchobdellids, Glossiphonia complanata L., 1758; Helobdella stagnalis L., 1758 at two developmental stages (larva / adult), and the arhynchobdellids, Erpobdella octoculata L., 1758; E. nigricollis Brandes, 1900, was investigated. The differences between the two orders of leeches are revealed in the ultrastructure of the rhabdom, the rhabdomeres, periphaosomal zone, and pigmented granules. The rhynchobdellid eyes are characterized by a compact rhabdom, ovoid-spherical phaosomal rhadbomeres, relatively short microvilli, and one type pigment granules in supported pigmented cells of eyes. The unique characteristic of the Rhynchobdellida is the apical centrioles in the phaosomal photoreceptoral cells. For the Arhynchobdellida the features are the less compact rhabdom which separated by an extracellular matrix, ovoid-flattened rhabdomeres, and two types of pigment granules. The unique characteristics of the Arhynchobdellida are distinct zones in the periphaosomal cytoplasm: inner, reticular and outer, mitochondrial layers. The successive events of development of eyes after hatching are as follows: formed clusters of phaosomal photoreceptor cells, associated with pigmented cells or not, move, gradually, rhabdom constitutes compact and becomes surrounded by the pigmented cells of the eye cup. Meanwhile, the phaosomal rhabdomers become rounded up, microvilli elongate, and a stalk appears. Pigmental cells undergo structural changes as well.

How to cite this article: Shakurova N.V., Gataullina A.R. 2017. A comparative ultrastructural analysis of eyes in leeches (Hirudinea: Rhynchobdellida, Arhynchobdellida) // Invert. Zool. Vol.14. No.2. P.190-196. doi: 10.15298/invertzool.14.2.14
\end{abstract}

KEY WORDS: Rhynchobdellida, Arhynchobdellida, ultrastructure, eye cup, phaosome, larval eyes

\section{Сравнительный ультраструктурный анализ глаз пиявок (Hirudinea: Rhynchobdellida, Arhynchobdellida)}

\section{Н.В. Шакурова, А.Р. Гатауллина}

Казанский (Приволжский) федеральный университет, ул. Кремлевская, 18, г. Казань, 420008, Pоссия. E-mail: ntlshakurova@gmail.com

РЕЗЮМЕ: Hirudinea представляют собой уникальную группу среди Clitellata, поскольку только у них широко распространены сложные фаосомальные органы глаза. Однако последние ультраструктурные исследования глаз пиявок датируются 60 -ми годами XX века. Нами исследовано тонкое строение глаз ринхобделлид 
Glossiphonia complanata L., 1758; Helobdella stagnalis L., 1758 на двух стадиях развития (личиночная / половозрелая), а также аринхобделлид Erpobdella octoculata L., 1758; E. nigricollis Brandes, 1900. Отличия глаз пиявок этих двух отрядов проявляются в организации рабдома, ультраструктуре рабдомеров, перифаосомальной цитоплазмы, пигментных гранул. Для Rhynchobdellida характерными признаками являются компактный рабдом, овоидно-шаровидные фаосомальные рабдомеры, относительно короткие микровилли, отсутствие зонирования перифаосомальной цитоплазмы как у личинок, так и у взрослых червей, а также единственный тип пигментных гранул в опорных пигментных клетках глаза. Уникальной чертой для глаз ринхобделлид являются апикальные центриоли в фаосомальных фоторецепторных клетках. У Arhynchobdellida рабдом менее плотный, поскольку между фоторецепторными клетками есть изоляция в виде межклеточного вещества; овальные рабдомеры уплощены, в пигментных клетках - два типа гранул. Специфической чертой глаз аринхобделлид является зонирование цитоплазмы в районе фаосомы с четким выделением внутреннего ретикулярного слоя и внешнего - митохондриального. Установлена последовательность изменений структуры глаз в постэмбриогенезе после вылупления. Начинается этот процесс у ринхобделлид с перемещения кластеров фоторецепторных клеток, залегающих либо совместно с пигментными клетками либо на небольшом расстоянии от них. Постепенно рабдом становиться компактным и окружается пигментными клетками глаза. При этом фаосомальные рабдомеры приобретают шаровидную форму, микровилли удлиняются, а между сомой и сенсорным доменом возникает сужение - стебелек. Структурные изменения затрагивают и пигментные клетки.

Как цитировать эту статью: Shakurova N.V., Gataullina A.R. 2017. A comparative ultrastructural analysis of eyes in leeches (Hirudinea: Rhynchobdellida, Arhynchobdellida) // Invert. Zool. Vol.14. No.2. P.190-196. doi: 10.15298/invertzool.14.2.14

КЛЮЧЕВЫЕ СЛОВА: Rhynchobdellida, Arhynchobdellida, ультраструктура, глазной бокал, фаосома, личиночные глаза.

\section{Introduction}

Differences in sensory perception and mobility between the Errantia and Sedentaria groups of the Annelida are used as a basis for the modern analysis of annelid evolution and phylogenetic relationships (Struck et al., 2011; Purschke et al., 2014). One of the major groups of the Sedentaria clade is Clitellata including Hirudinea and Oligochaeta. Interestingly, leeches of the genus Helobdella are generally referred to as the model organism for the clitellates, one of the feeder types in Sedentaria (Struck et al., 2011; Purschke et al., 2014). However, in terms of the specifics of sensory perception systems, the Hirudinea are unique among the Clitellata, since they have a complete phaosomal organs - pigmented eyes - that are widespread only in this group (Purschke, 2006). In fact, phaosomal eyes are considered to be a characteristic feature of leeches, resulting in the interchangeability of the terms 'phaosomal' and 'hirudinean' (Hansen, 1962; Eakin, 1982; Purschke et al., 2006). Phaosome is one of the three described types of photoreceptor cells in annelids, along with rhabdomeres and ciliary cells (Eakin, 1982; Purschke, 2006). Phaosomal cells constitute a special type of microvillar photoreceptor cells whose light-sensitive processes extend into the cavity of the intracellular vacuole, not outwards as in rhabdomeric or ciliary photoreceptor cells.

Among the few works on electron microscopic examination of the ultrastructure of leech 
eyes, the works by Hansen (1962), Clark (1967), and White and Walther (1969) are the most comprehensive. Observations on the arhynchobdellid leeches consider only Hirudo medicinalis (Rohlich, Torok, 1964). Because so little attention has been paid to the group so essential in solving the problems of evolutionary morphology of annelids, the present work aims to produce a detailed description of the eye ultrastructure of leeches in two existing orders of the Euhirudinea: Rhynchobdellida and Arhynchobdellida.

\section{Materials and methods}

This study was performed on four species of leeches of two orders - Rhynchobdellida(Glossiphoniidae: Glossiphonia complanata Linnaeus, 1758; Helobdella stagnalis Linnaeus, 1758) and Arhynchobdellida (Erpobdellidae: Erpobdella octoculata Linnaeus, 1758; E. nigricollis Brandes, 1900) of the subclass Euhirudinea. The classification of Hirudinea follows Lukin (1976) and Sawyer (1989). In order to study the morphological transformations of the eyes in postembryogenesis, larval and adult stages of arhynchobdellids were obtained. Larvae of species Helobdella stagnalis (one-day stage after hatching) and Glossiphonia complanata (threeday stage) were used. The leeches were collected from the littoral zone of the Volga river and maintained in the laboratory at the zoology department at the Kazan University until used.

For transmission electron microscopy studies, samples were prepared according to a standard method. Decapitated adult leeches and whole 1-3 day larvae were fixed in a $1 \%$ solution of glutaraldehyde, followed by $2 \%$ osmium tetroxide. All fixatives were buffered to $\mathrm{pH} 7.4$ with $0.1 \mathrm{M}$ phosphate. Dehydratation was performed in graded concentrations of ethanol, and samples were embedded in an Epon-812-MNADDSA mixture (SERVA, Germany). Ultrathin sections (50 nm) obtained on Ultracut E Reichert (Reichert, Austria) were stained with uranyl acetate and lead citrate and examined in an electron microscope JEM-100 CX (JEOL, Japan).

\section{Results}

General features. The eyes of leeches in all the species we studied are complicated multicellular organs of the chamber type. They consist of multiple pigment cells that form eye cup, 2-5 dozen phaosomal photoreceptor cells lying in several rows in the eye cavity and a connective-tissue capsule that forms not only the transparent cornea on the pupil side, but also an inner and outer lining of the eye (Fig. 1A). The thickness of the fibrous capsule of the eye $(1.5-5 \mu \mathrm{m})$ is significantly less than that of the pigmented eye cup $(10-16 \mu \mathrm{m})$. Photoreceptor cells (PRCs) of both rhynchobdellid and arhynchobdellid leeches are divided into two domains: sensory (phaosomal-rhabdomeric) and somatic (nuclear), both located inside the eye cavity. The sensory part contains microvilli emerging from a phaosome membrane that is deep inside the cytoplasm of the dendrite. Most of the significant differences that we have discovered in the eye ultrastructure of leeches from different orders appear in the sensory part of the PRCs and are described in more detail later. Each microvillus has a dense bundle of actin filaments that serves as its structural core (Fig. 1D, E). We have not found an evident connection between the phaosomal membrane and the outer membranes of PRCs, but we have discovered deeply adhered folds of the outer membrane that may compose the highly convoluted connection between the outer surface and the phaosomal membranes. Previously, it was shown by lanthanum deposition that such folds and clefts connect the phaosome with the extracellular space in leech eyes (White and Walther, 1969). The soma of a photoreceptor cell contains a nucleus of regular oval shape with electron-light nucleoplasm and a well-developed endoplasmic reticulum, Golgi complex, mitochondria, and microtubules. Between the sensory domain and the soma of the cell, there is a very short (compared with the real rhabdomeric photoreceptor cell of other annelids) interception of cytoplasm known as a stalk. Axons of PRCs form the optic nerve. The location of this nerve differs in various orders; in the 

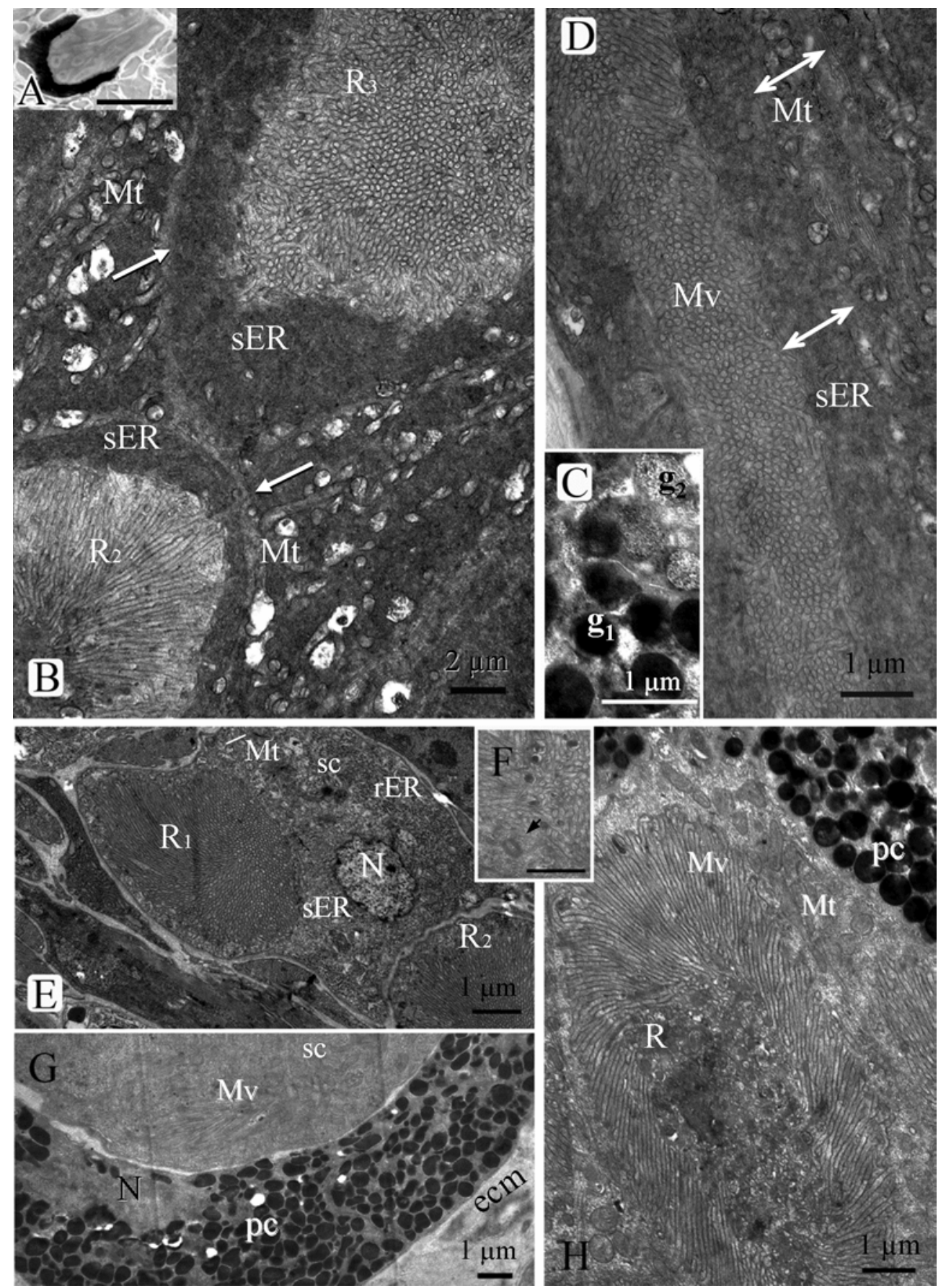

Fig. 1. Ultrastructure of the eyes of the Arhynchobdellida (A-D) and Rhynchobdellida (E-H). A - the longitudinal section the eye of Erpobdella octoculata L., 1758, bright field image, scale bar:50 $\mu \mathrm{m}$; B the rhabdomers of E. octoculata Brandes, 1900, in the periphaosomal space the mitochondrial and reticular zones are separated by a narrow layer of electron transparent cytoplasm (arrows); $\mathrm{C}$ - two types of pigment granules (E. nigricollis); D - the flattened rhabdomers of E. nigricollis, three functional compartments are 
Rhynchobdellida, it is on the edge of the pigmented cup, while in the Arhynchobdellida it goes through the middle of the wall of the pigmented cup. Yet, in both cases, the rhabdomeres of the PRCs are directed both towards and away from the incoming light. As a result, these leeches' eyes turn out to be simultaneously everse and inverse, demonstrating the socalled 'mixed type'. This characteristic is well known also for other taxa of animals with rhabdomeric photoreceptors - for Plathelminthes, Nemertea (Shakurova, 2009), Annelida (Purschke, 2006), Mollusca (Nilsson, 2013).

Rhynchobdellida. We studied the eye ultrastructure of the leech species Glossiphonia complanata L., 1758 - the typicale species of the family Glossiphoniidae - at two developmental stages: three-days larva and adult. We also specified a number of ultrastructural and morphometric details of the eyes of Helobdella stagnalis L., 1758, as an addition to the description of the fine structure of adult $H$. stagnalis eyes published earlier by Clark (1967).

Adult eyes. Glossiphonia complanata has three pairs of eyes located on the third through fifth rings (not segments) of the body, while $H$. stagnalis has one pair of eyes located on the third ring of the body. Each eye of G. complanata and H. stagnalis consists of 3-5 rows of tightly packed photoreceptor cells located inside an elongated, pigmented, multicellular cup, the hole of which is closed by a fibrous capsule of extracellular matrix. Phaosomal rhabdomeres are of ovoid-spherical shape $(8 \times 5 \times 9 \mu \mathrm{m}$ in G.complanata; $7 \times 6 \times 10 \mu \mathrm{m}$ in $H$. stagnalis) (Fig. $1 \mathrm{H}$ ). The average length and diameter of microvilli are $3.8 \mu \mathrm{m}$ and $95 \mathrm{~nm}$ in adult $G$. complanata, respectively, and $2 \mu \mathrm{m}$ and $90 \mathrm{~nm}$ in H. stagnalis. In G. complanata and H. stagnalis, the submicrovillar space of the sensory domain of the PRC is narrow $(0.2-0.6 \mu \mathrm{m})$ and contains aggregations of mitochondria and smooth endoplasmic reticulum (Fig. 1H). The pigment cells have numerous granules $(0.2-0.6$ $\mu \mathrm{m}$ in diameter) with a homogenous electrondense material similar to melanin (Fig. 1H). Extracellular matrix surrounds the eye from the outer side, lines the inner surface of the optic cavity, and isolates the photoreceptor and pigment cells. The thickness of this isolating layer

visible: microvillar, reticular, and mitochondrial; E - the larval eye of Helobdella stagnalis L., 1758: the cluster of phaosomal photoreceptor cells distanced from pigmented cells; F - the apical centriole (arrow) in the larval eye of rhynchobdellids (Glossiphonia complanata L., 1758), scale bar:1 $\mu \mathrm{m} ; \mathrm{G}$ - the larval eye of G. complanata: the phaosomal photoreceptor cells associated with pigmented cells (the same is observed in H. stagnalis); $\mathrm{H}$ - the adult eye of G. complanata: ovoid-spherical rhabdomere, the intracellular vacuole (phaosome) bears numerous microvilli, the periphaosomal cytoplasm contains of mitochondria and smooth endoplasmatic reticulum.

Abbreviations: ecm - extracellular matrix, $\mathrm{Mt}$ - mitochondria, $\mathrm{Mv}$ - microvilli, $\mathrm{N}$ - nucleus, $\mathrm{g}_{1,2}$ - two types of the pigment granules, $\mathrm{pc}$ - pigmented cell, $\mathrm{rER}$ - rough endoplasmatic reticulum, $\mathrm{R}_{1-3}$ - rhabdomeres of sensory cells, sc - sensory cell, sER — smooth endoplasmatic reticulum.

Рис. 1. Ультраструктура глаз пиявок отрядов Arhynchobdellida (A-D) и Rhynchobdellida (E-H). A продольный срез глаза Erpobdella octoculata L., 1758, снимок в режиме светлого поля, масштабная линейка: $50 \mu \mathrm{m}$; В - рабдомеры E. octoculata Brandes, 1900, в перифаосомальном участке видны разделенные слоем прозрачной цитоплазмы митохондриальная и ретикулярная зоны (стрелки); $\mathrm{C}$ два типа пигментных гранул (E. nigricollis); D - уплощенный рабдомер E. nigricollis, видны три функциональных компартмента: микровиллярный, ретикулярный и митохондриальный; Е - личиночный глаз Helobdella stagnalis L., 1758: скопления фаосомальных фоторецепторных клеток удалены от пигментных клеток; F - апикальная центриоль (стрелка), личиночный глаз ринхобделлид (на примере Glossiphonia complanata L., 1758), масштабная линейка: $1 \mu \mathrm{m} ; \mathrm{G}$ - личиночный глаз G. complanata: фаосомальные фоторецепторные клетки расположены вместе с пигментными клетками (такая же картина наблюдается и у H. stagnalis); Н - глаза взрослых пиявок G. complanata: овоидно-сферический рабдомер, внутриклеточная вакуоль (фаосома) образует многочисленные микровилли, перифаосомальная цитоплазма содержит митохондрии и гладкий ретикулум.

Обозначения: ecm — внеклеточный матрикс, $\mathrm{Mt}$ - митохондрии, $\mathrm{Mv}$ - микровилли, $\mathrm{N}$ - ядро, g 1,2 - два типа пигментных гранул, pc - пигментированные клетки глаза, $\mathrm{rER}$ — гранулярный эндоплазматический ретикулум, $\mathrm{R}_{1-3}$ - рабдомеры сенсорных клеток, sc - сенсорные клетки, sER - гладкий эндоплазматический ретикулум. 
is, on average, $0.25 \mathrm{~nm}$ in Glossiphonia complanata (the larger leech) and $0.15 \mathrm{~nm}$ in Helobdella stagnalis (the smaller leech). There is no extracellular matrix between the receptor cells.

Larval eyes. In Glossiphonia complanata larvae, instead of three pairs of anterior eyes, there are two pigmented rows, each containing three tightly packed eyes. In Helobdella stagnalis larvae, there is one pair of eyes. Generally, the structure of larval rhynchobdellid eyes corresponds to that described for adult leech eyes. The successive events of development of eyes are as follows: formed clusters of phaosomal photoreceptor cells (Fig. 1E, G), associated or not with pigmented cells, move (as one could observe in the one-day larvae of H. stagnalis), gradually, rhabdom constitutes compact and becomes surrounded by the pigmented cells of the eye cup. Meanwhile, the phaosomal rhabdomers rounded up, microvilli elongate, and a stalk appears. Pigmented cells, initially incoherent, become closer and form an eye cup. Pigmented cells change their shape from prismatic in larvae to multifaceted in adults. The nucleus of pigmented cells moves from the centre to the outer edge, and the shape of pigmented granules transforms from polygonal to spherical (Fig. 1G, H). The most distinctive differences were discovered among younger, one-day-old leeches. In the one-day larva of $H$. stagnalis, the rhabdoms are smaller $(4 \times 3 \times 7$ $\mu \mathrm{m})$ compared to the ones in adult leech eyes, while in the three-day larva of G. complanata, the rhabdoms are already the same size as in adults. The microvilli of the larval eyes in both species are shorter by 2-2.5 times than in adults and narrower; in one-day larvae of $H$. stagnalis, the width of the microvilli is half the diameter it is in adult eyes, and the width in three-day larvae of $G$. complanata is $80 \%$ of microvilli in adults. The somatic and sensory parts of the photoreceptor cells in one-day larval eyes of $H$. stagnalis are not separated but pulled together (Fig. 1E). However, in three-day larvae of G. complanata, a short, narrow stalk appears, the same as in adult leech eyes. The submicrovillar area of the sensory domain does not change significantly in the course of growth. However, in this area of the larval eye, we have identified a few apical centrioles, with a diameter of about 150 $200 \mathrm{~nm}$ (Fig. 1F). In larval G. complanata and $H$. stagnalis, apical centrioles in photoreceptor cells are described for the first time here. Previously, nuclear centrioles were found in adult leeches Helobdella stagnalis and Placobdella rugosa (Clark, 1967). In our opinion, the presence of apical centrioles is a general, presumably rudimentary, characteristic for the Glossiphoniidae.

Arhynchobdellida. The eyes of Erpobdella octoculata L., 1758 and E. nigricollis Brandes, 1900 differ in the structure of their sensory domains; the rhabdom is formed by 6-7 rows of rhabdomeres with a flattened oblong shape $(7 \times$ $2 \times 14 \mu \mathrm{m})($ Fig. 1B,D). The microvilli are a bit larger than those in rhynchobdellid eyes, with an average length of $3 \mu \mathrm{m}$ and diameter of $120 \mathrm{~nm}$ in E. nigricollis; the length and diameter in $E$. octoculata are 3 and $140 \mathrm{~nm}$, respectively. The volume of a singular cylindrical microvillus is 3.4 or $4.6 \mu \mathrm{m}^{3}$ for E. nigricollis and E. octoculata, respectively, while for rhynchobdellid specimens it is $1.3-2.7 \mu \mathrm{m}^{3}$. In arhynchobdellids, the periphaosomal area is, on average, four times thicker than in rhynchobdellids (1.5-2 and 0.2$0.6 \mu \mathrm{m}$, respectively). Almost half of this volume is taken up by the submicrovillar layer of the well-developed smooth endoplasmatic reticulum (Fig. 1B, D). The mitochondria are located peripherally. Thus, in Erpobdella, the sensory segment of the photoreceptor cells is obviously divided into three zones: 1) the internal compartment, which is a microvillar photodetector; 2) the middle compartment, a reticular depot of $\mathrm{Ca}^{2+}$ ions participating in the process of phototransduction; and 3) the external compartment, the main components of which are mitochondria, the rough reticulum, dictyosomes, making it a zone of high metabolic activity (Fig. 1D). Such structure of a sensory segment is described here for the first time for arhynchobdellid leeches and is apparently universal for this order. In the E. octoculata, the mitochondrial and reticular zones are separated from each other by a narrow layer of clear cytoplasm (Fig. $1 \mathrm{~B}$, arrows). This characteristic is inherent only to E. octoculata. 
Unlike in the Rhynchobdellida, the fibrous layer not only detaches the pigmented cells from the sensory cells, but also isolates each photoreceptor cell.

For the Arhynchobdellida, unlike the Rhynchobdellida, there are two types of the pigment granules: those with highly electron-dense amorphous material (Fig. 1B) and those with moderately electron-dense grainy material (Fig. 1C). Yet, the sizes of the granules of both types are similar $(0.2-0.6 \mu \mathrm{m})$.

As a results, the differences between the two orders of the leeches are revealed in the ultrastructure of the rhabdom, the rhabdomeres, periphaosomal zone, and pigmented granules. For the Rhynchobdellida characteristic features are the compact rhabdom, ovoid-spherical phaosomal rhadbomeres, relatively short microvilli, absence of compartmentalization in periphaosomal cytoplasm in larvae or in adults, and one type pigment granules in supported pigmented cells of eyes. The unique characteristics of the Rhynchobdellida are the apical centrioles in the phaosomal photoreceptoral cells. For the Arhynchobdellida characteristic features are the less compact rhabdom in which phaosomal rhabdomeres are separated by an extracellular matrix, ovoid-flattened rhabdomeres with long microvilli, and two types of pigment granules. The unique characteristics of the Arhynchobdellida are distinct zones in the periphaosomal cytoplasm: inner reticular and outer mitochondrial layers. Thus, the revealed ultrastructural features, not just the phaosomes, have a taxonomic specificity for the two orders - Rhynchobdellida and Arhynchobdellida — and can be used in the phylogenetic analysis of the Hirudinea and their relationship to other annelids.

\section{References}

Clark A.W. 1967. The fine structure of the eye of the leech Helobella stagnalis // J. Cell Sci. Vol.2. P.342-348.

Eakin R.M. 1982. Continuity and diversity in photoreceptors // Westfall J.A. (ed.). Visual Cells in Evolution. New York: Raven. P.91-105.

Hansen K. 1962. Elektronenmikroskopischen Untersuchung der Hirudineen-Augen//Zool. Beitr. N.F. Vol.7. P.83-128.

Lukin E.I. 1976. [Leeches of fresh and brackish water reservoirs] // Fauna SSSR. No.109. Leningrad. 484 p. [In Russian]

Nilsson D.E. 2013. Eye evolution and its functional basis // Vis Neurosci. Vol.30. P.5-20.

Purschke G., Arendt D., Hausen H., Muller M.C.M. 2006. Photoreceptor cells and eyes in Annelida // Arthropod Struct. Dev. Vol.35. P.211-230.

Purschke G., Bleidorn C., Struck T. 2014. Systematic, evolution and phylogeny of Annelida - a morphological perspective. // Memoirs of Museum Victoria. Vol.71. P.247-269.

Rohlich P., Torok L. 1964. Electronenmicroscopische Beobachtungen an den Sehzellen des Blutegels, Hirudo medicinalis. // Z. Zellforsch. microsk. Anat. Bd.63. S.618-635.

Sawyer R.T. 1986. Leech Biology and Behavior. Oxford: Clarendon Press. 1065 p.

Shakurova N.V. 2007. [The ultrastructure analyzes of photoreceptoral system of Nemertea in light phylogeny state of the phylum] // Uchenye Zapiski Kazanskogo gosudarstvennogo universiteta. Estestvennye nauki. Vol.149. No.3. P.148-154 [in Russian, with English summary].

Struck T.H., Paul C., Hill N., Hartmann S., Höse C., Kube M., Lieb B., Meyer A, Tiedemann R., Purschke G., Bleidorn G. 2011. Phylogenomic analyses unravel annelid evolution // Nature. Vol. 471. P.95-98.

White R.H., Walther J.B. 1969. The Leech Photoreceptor Cell: Ultrastructure of Clefs Connecting the Phaosome with Extracellular Space Demonstrated by Lanthanum Deposition // Z. Zellforsch. Vol.95. P.102108 .

Responsible editor E.N. Temereva 